\title{
Barriers to Development: Terrorism, Corruption and Social Violence
}

\author{
Pooja Singh \\ (Research Scholar, Singhania University)
}

\begin{abstract}
BARRIERS TO DEVELOPMENT India has made significant in-roads on its path to development. A country reeling at the literacy rate of $18.35 \%$ in 1951 has achieved a significant literacy rate of $65.38 \%$ by 2001. India plays a vital role in the software industry in the modern world. At the times of recession, while the rest of the world had its back on the grounds, India was among the few countries that managed to continue with a positive growth rate.

Apart from all the significant changes that have happened in 64 years of Independence, India still have a lot of issues to worry about? India's population base is enlarging every moment, standing as the $2^{\text {nd }}$ most populous nation; it is set to topple china in sometime.

With $26 \%$ population under the poverty line, $35 \%$ of the population lives on less than $1 \$$ a day and $80 \%$ less than 2\$. Initiatives have been taken like the National Literacy Mission and the Sarva Siksha Abhiyan for achieving 100\% literacy, Yet India has faltered to do so till 2011.

$15 \%$ of population still does not get potable water to drink and India ranks No. 1 in maternal Mortality rate and Road accidents. What makes India so unsafe, undeveloped for its citizens, while we wrap her in non-existing banner of "India Shining"? While the issues in development are numerous, we talk about three main issues:
\end{abstract}

\section{- Terrorism}

Any evaluation of development potentials needs to take into account the influence of internal and external social stability on social progress. A country that is targeted on a everyday basis by not just external forces as well as the internal terrorism, cannot strive for social development. India is surrounded by hostile countries from both sides, be it China or Pakistan. If everyday infiltration wasn't an issue to worry about, India now faces new homegrown threats, which are a more serious area of concern then across border intrusion.

In this paper, we look to find out what exactly India faces, how it plans to deal with terrorism and what more is required?

\section{- Corruption}

Corruption is defined as lack of integrity or honesty (especially susceptibility to bribery); use of a position of trust for dishonest gain. Corruption is just like terrorism; in white clothes i.e. it eats away the country from the inside. Be it the Commonwealth scam or the Adarsh Housing scam or the more recent 3G scam, India faces serious corruption issues from its incumbents and other political leaders.

So much is wrath of corruption, that perhaps the most reputed man in politics, Mr. Manmohan Singh, the brain behind India's economy couldn't control his own government not to be a prey to corruption. In our paper, we look forward to finding what exactly corruption is, how India fares in comparison to the world and what is required not just from the government but also from the citizens of India.

\section{- Social Violence}

India is country of diversities, be it based on languages, religion or regions, India have always been proud of the fact that its progress and its democracy has surged forward irrespective of its disparities.

It is a pity to see that politicians using this disparity for their own vote bank. India has been witness to civil unrest and massive clashes in the country, be it the communal riots in Gujarat or riots based on reservation of seats or for separate state.

In this paper, we try to find more such incidents and what can be done against them?

Keywords: Barriers, Corruption, Development, Social Violence, Terrorism.

I. Barriers to Development: Terrorism, Corruption and Social Violence

India has progressed very far from its modest origin. The kind of growth India has witnessed in every possible domain ranging from economic reforms to agricultural and rural development or the educational/health sector has been nothing short of marvelous journey. 
Barriers to Development: Terrorism, Corruption and Social Violence

The economy of India of the $21^{\text {st }}$ century stands at $11^{\text {th }}$ largest in the whole world in terms of GDP (Gross Domestic Product) and $4^{\text {th }}$ largest in terms of PPP (Purchasing Power Parity). Economists predict that by 2020, India would be one of the leading economies of the world fuelled by the kind of brain-power and manpower it possesses. The development can be understood from the fact that it was based on socialdemocratic policies from 1947-1991. The economy was characterized by extensive regulation, protectionism, public ownership and large-scale corruption. In economic terms, India has progressed from a closed-social democratic economy to market economy. India's total trade in goods and services has reached a share of $43 \%$ of GDP in 2005-06, up from $16 \%$ in 1990-91. Over the last few years, India has embraced the path of development, largely in sectors of Energy, Education, Health, Agriculture and Rural Development. Considering agriculture and rural development, after the partition Indian agricultural sector predominantly was marred by feudal land relations and low employment and under employment leading to low productivity per hectare or per field. The farmers were poor, most of them under poverty line. The green revolution (1962) brought to our country the much required changes and the kind of help farmers required.

Operation flood, also called the White revolution of India resulted in India being the largest milk and related milk producer in the world. It also helped reduce malpractices by milk traders and merchants. This revolution followed the Green Revolution and helped in alleviating poverty and famine levels from their dangerous proportions in India during the era. India made serious inroads in the period of 1947 to 2001, in the field of education sector. In 1947, a time when India was reeling at a dismal literacy rate of $18.35 \%$ to a literacy rate of $65.38 \%$ in 2001 is a commendable task.

India also made its presence felt in the health sector with the life expectancy increasing from 32 years in 1947 to 63.7 in 2008, source: World Bank. Apart from that, India has developed in other aspects as well. It can be Transport or Industries or any such particular sector as well. India progressed significantly with the help of its industries as well. Post-Independence India relied on the coal industries that were setup in the late 1800's, Textile and sugar Industry in the first half of $20^{\text {th }}$ century, Iron and steel industry in the year 1905 and the cement Industry in the 1930's. The biggest contribution to the industrial sector was the birth of Tata Consultancy Services (1968) that marked India's venture in the field of Software Industry. India is one of the largest IT capitals in the modern world, accounting for over 5\% of country's GDP and employing over 2 million people. Apart from all the significant changes that have happened in 64 years of Independence, India still have a lot of issues to worry about? India's population is growing every minute standing at $2^{\text {nd }}$ most populous nation, set to topple China in a few years time.

India is among the only few nations in which Polio exists, it has the maximum number of AIDS cases in the world and houses a few other epidemics of large scale. India aimed at providing at $100 \%$ literacy by the year 2012, an initiative it has failed drastically. More than 10 million people have no access to electricity and an equivalent amount have no potable water to drink. India is the world leader in Maternal Mortality Rate and road accidents. What makes India so unsafe, undeveloped for its citizens while we wrap her in a non existing banner of "India Shining"? While there might be a plethora of reasons, we would address three basic reasons:

\section{TERRORISM}

Terrorism, according to the Wikipedia is the systemic use of terror especially by the means of coercion. Common definition of terrorism refer to those violent acts which are intended to create fear are perpetrated for a religious, political or ideological goal, deliberately target or disregard the safety of civilians, and are committed by non-government agencies. Terrorism has a negative impact on the development of any nation, particularly a nation like India.

In a country like India, Terrorism can be due to several issues. While terrorism includes issue like poverty as well, the terrorism in India is mostly cross border. No one can really estimate the consequences, the price and the cost of the impact of terrorism on our country or the amount of funding that is spent each year as "war on terrorism". The kind of amount spent every year on fighting the war against terrorism or to keep the borders guarded with a constant vigil to fight insurgency is enormous. Mr. Arun Jaitley in the Lalit Doshi Memorial on August 2, 2002 provided a figure quoting "The total amount of money spent and this doesn't include the amount that we spent on our security forces, army and so on, on merely relief and rehabilitation, on the special paramilitary forces that we deploy for anti-insurgency - the figure now crosses Rs.45, 000 crores. More than Rs. 45,000 crores is what is deprived to our villages in terms of electricity and power, in terms of health care, in terms of education, in terms of roads. That is the kind of money which has actually been employed in just the anti-insurgency measures."

A budget jump of over $2600 \%$ for anti-insurgency is the amount of money India cannot afford to lose every year. While $15 \%$ of Indians strive for potable water and 77\% BPLR still struggle to make their ends meet, terrorism does hinder India's development in all aspects.

There is another great aspect -- as to what are the other hidden costs, which are involved as far as terrorism is concerned. Firstly, there is a large political cost. The political cost involved is that terrorism tends to undermine 
democratic values. It undermines democratic institutions. It assaults each one of them and then a feeling gains ground that in order to deal with terrorists, you need certain strong methods to deal with them and therefore you have to depart from what is the chosen democratic cause itself It has an adverse effect as far as economic growth and development is concerned. How much did one of India's most affluent States, the Punjab, suffer on account of terrorism in 10 years?

The attack on Mumbai was an attack on the "spirit of India". The scale of the attack, the orchestration put one thing on the table: India is in war, a war with terrorism and has deadly enemies in its midst. India's divisive political culture, in which numerous parties, showing little or no spirit of cooperation, constantly battle each other for regional or national power, that has played a considerable part in allowing terrorism to breed. India's political system needs to be overhauled so that not only development of this country comes on track but also strict security enforcement comes into motion. It is time that a zero tolerance policy towards terrorism is adopted rather than providing the terrorists a shelter in our prisons and arising possibility of another IC-814 hijack.

Terrorism also has an impact on the industrial sector if our economy. While the immediate effect maybe short lived but terrorism instills a fear in not only the workers and the entrepreneurs but also affects foreign investments that would have helped in our development. No investor would like to invest in a country that faces a terrorism onslaught every few months in some part of the country or another. Tourism is one of the first areas to be hit, with hospitality and transportation feeling the pain the most.

According to Wikipedia, Tourism is the largest service industry in India, with a contribution of $6.23 \%$ to the GDP and $8.78 \%$ of the total employment in India. India witnesses' more than 5 million annual foreign tourist arrivals and 562 million domestic tourism visits. The Taj Mahal alone receives a footfall of over 3 million every year from other countries. Apart from the investments, India's reputation as a tourist-friendly country comes into jeopardy with most of the foreign tourists shying to go a country that is so unstable. An effect that would of course be felt like other tourism related industries like hospitality and hotel industries and the transportation and the local tour operators. According to World Travel and Tourism Council, India will be a tourism hotspot from 2009-2018, having the highest 10-year growth potential. The Travel \& Tourism Competitiveness Report 2007 ranked tourism in India 6th in terms of price competitiveness but 39th in terms of safety and security. A country with such enormous tourism potential needs to take into consideration the safety of tourists before looking for development in this particular sector.

Terrorism not just affects the nation; it affects the nation as well. The relationship between India, a democratic nation and terrorism is very complex. Every democratic nation faces the wrath of terrorism. While a democratic nation espousing civil liberties may claim a sense of higher moral ground than other regimes, an act of terrorism within such a state may cause a dilemma: whether to maintain its civil liberties and thus risk being perceived as ineffective in dealing with the problem; or alternatively to restrict its civil liberties and thus risk delegitimizing its claim of supporting civil liberties.

Creating real hope is our main weapon in the fight against terrorism. To counteract the climate of despair and revolt there must be visible signs of hope for improvement in human rights, economic, social, cultural, political. While the trade-off between development and terrorism would continue to exist, I would like to point out at a very interesting solution provided by Kim Cragin and Peter Chalk in their publication "Terrorism and Development" for RAND in which they effectively list five points that would help in weakening terrorism:

1. Social and economic development policies can weaken local support for terrorist activities: According to the report, creating a middle class that would help in strengthening against terrorism rather proterrorism.

2. Social and economic development can discourage terrorist recruits.

Since many terrorists belong to communities that have grievances against the government, strengthening and providing economic development would result in less local terrorists.

3. Inadequately funded social and economic policies are likely to inflate expectations and renew support for terrorism.

4. Incomplete hopes or hopes of revival which are not often completed may lead to support from terrorist groups once again.

5. The ability of development policies to inhibit terrorism depends on their implementation.

6. Social and economic development policies do not eliminate terrorism.

\section{CORRUPTION}

Corruption is one of the most pervasive problems India faces. Corruption flows deep into Indian Economy and is a major setback to her development. India reformed its economy in 1991 to reduce red tapeism and reduce the widespread corruption in India during the socio-democratic economy before 1990 but hasn't been able to successful reduce corruption. Be it the recent Commonwealth Games scandal or the $2 \mathrm{G}$ Sham or the 
much-hyped less-done Bofors Scandal in the 1980's, corruption is something prevalent in every level and every region of our country. Bofors Scandal is supposed to be in the tune of Rs. 400 Crores in the 80 's, a period itself when India was reeling from poor economy. The much recent Commonwealth Games 2010 made mockery of the Indian Government with the following excerpt from Wikipedia, "The initial total budget estimated by the Indian Olympic Association in 2003 for hosting the Games was ₹1,620 crore (US\$351.54 million). In 2010, however, the official total budget soon escalated to an estimated ₹11,500 crore (US $\$ 42.5$ billion), a figure which excluded non-sports-related infrastructure development. Business Today magazine estimated that the Games cost ₹60,000 crore (US $\$ 13.02$ billion). The 2010 Commonwealth Games are reportedly the most expensive Commonwealth Games ever."

The recent scandals that hovered the limelight was the $2 \mathrm{G}$ scam which has not only involved top ministers but has also taken India back to the tune of over 1.76 Lakh Crores, a figure so large that could have helped in changing the face of India and helped it address issues of development.

The economic reforms of 1991 reduced the red tape, bureaucracy and the License Raj that had strangled private enterprise and was blamed for the corruption and inefficiencies. Yet, a 2005 study by Transparency International (TI) India found that more than half of those surveyed had firsthand experience of paying bribe or peddling influence to get a job done in a public office.

A study by Transparency International, 2005 provides the statistics that truckers provide US $\$ 5$ billion as bribes to government officials. Political Corruption is one of the major concerns for India with its rank slipping to $87^{\text {th }}$ most corrupt country out of 178 in the year 2010 .

The Vohra (Committee) Report by the India's Union Home Secretary Mr. N.N Vohra in October, 1993 explained about the nexus between the politicians, bureaucrats and the criminals. The Supreme Court has been demanding action on the Vohra Report ever since, with no considerable success.

The fight to corruption is required to be given a central position in any reform even that takes place inside our country. No proper development can take place if corruption isn't tackled. Corruption threatens development and security in every aspect. Corruption brings a sense of alienation in the people of any country especially India, where a common person views any bureaucrat, politician or any government post holder with different light and disregard. Apart from that corruption if unchecked, can cause a country ungovernable due to a large public outcry and may lead to chaos and war. India needs to check its stance on corruption as well, if the government needs to continue its functioning with the public support. Corruption also hampers development in the sense that it increases the transaction cost of any government service that takes place while reducing the efficiency of the particular transaction. An example of this is the recently concluded Commonwealth Games in which all the materials bought for the Games were overpriced. Not only did it affect the reputation of the organizing committee and the Delhi Government in general but also hampered with the efficiency of the government with 70,000 Crores of taxpayer's money going into drain, a dramatic $1575 \%$ rise over the original budget for the games.

Corruption also hampers development as it reduces the state-revenue as most of the money goes in the pocket to satisfy the urge of the babus and other government officials. While the state could have made a more appropriate use of the money, it is indeed another chance lost by the government for the development of the nation. Corruption also affects development of the citizens as a whole not only in the terms that it alienates the common public from the new "elite" class, but also they have to face the burden of the corruption. Transparency International (2005) states that $75 \%$ of the common man in India has agreed to paying some form or another bribe or peddling influence to get a government job. Corruption is so common in an Indian's life be it in the form of bribing any traffic constable to escape challans or to pass a buck to any government incumbent to get the work done. The negative impact of corruption falls directly on its citizens and small scale industries that have to face the brunt of government agencies in order to survive. The brunt of corruption is faced by the poor and the unprotected that not only pay the required taxes and the rents but also pay the bribes to get the work done but often depriving them of the essential government services. Corruption takes away the chance from the state and the central government to provide a fair development and chance to bring economic reforms.

Corruption is particularly present in the judiciary, an institution that is supposed to uphold the rule of law. In some cases, judges extract bribes not only for delivering a verdict in a predetermined way but even for merely hearing a case. Lower order court clerks can also solicit bribes for producing or hiding certain information that is crucial to cases. The independence of the judiciary itself can be undermined by the executive branch influencing the appointment and promotion of judges. In such situations, judges are pressured to reach verdicts not based on justice but on political expediencies.

The conviction rate in corruption cases is as low as six percent, hence corruption has become low risk high profit activity for the people involved. Such is the poor state of our country, that an article on Wikipedia provides this excerpt "In July 2008 The Washington Post reported that nearly a fourth of the 540 Indian Parliament members faced criminal charges, "including human trafficking, immigration rackets, embezzlement, rape and even murder". An international watchdog conducted a study on the illicit flight of money from India, 
perhaps the first ever attempt at shedding light on a subject steeped in secrecy, concludes that India has been drained of $\$ 462$ billion (over Rs 20 lakh crore) between 1948 and 2008. The amount is nearly $40 \%$ of India's gross domestic product." Imagine what had been the outcome of our country, had this amount been spent on the development of the company rather than being spent on the non deserving government incumbents.

Corruption has managed to seep into every possible area a person can think of in India, be it Armed forces which includes the Sulekha Land Scandal or the Adarsh Society Scam or the police department which includes transfers and promotions based on corruption or attacking the innocent for the rich offenders hence putting a mark on the accountability of the police. While a lot has been said about how corruption has spread throughout country and how it has affected the development of our country, let us look at a few methods to curb corruption:

1. Sensitize the public against corruption

Most of the Indian Citizens have lost faith in the government thinking that no possible government work can be completed without bribing the officials starting from the very bottom and going till the top. Sensitizing the education system and providing the true education and enriching the society with issues like morals, values and ethics is required.

2. Reforming the Indian Judicial System

Stringent measures are required to curb corruption with strict actions against government officials who rely on public money for their benefit. Also the Indian Judiciary should ensure faster processing of cases and stricter sentences for the people involved.

3. Provide opportunities to the poor and the middle class

Most of the middle class and clerical employees take the route of corruption because of lack of incentives and income provided by the government as compared to the expenditure. Better salaries and better facilities are required to be provided at the clerical levels so that the poor may not suffer from the brunt of corruption.

4. Also distribution of money is very important, so that the decisions of monetary issues are not only vested to the rich but equally to the have-nots.

5. Privatization and Computerization of various departments

Implementing e-governance is a step that is not only required to facilitate seamless flow of information but also keep a check on corruption. E-Governance would provide a platform for the citizens of India to check what each government department is up to and would be able to provide its grievances not just against the particular department but also any particular person as well.

Privatization of defunct and corrupted department would not only provide the government a method to generate revenue but also curb the corruption in that particular department.

Few private sector initiatives have already been put into place like:

1. http://5thpillar.org is one such organization that is promoting the use of Zero Rupee Notes to fight corruption by shaming the officials who ask for bribe.

2. Another popular initiative Jaago Re! One Billion Votes from Tata Tea has now changed its focus from voter registration to fighting corruption.

3. Nobribe.org is another platform for corruption free India and advocates the use of direct and regular measurement of corruption to force the hands of the leadership into dealing with corruption related issues.

4. Another platform is http://www.indiaagainstcorruption.com India against Corruption is a movement created by concerned citizens from all spheres, and professions, who've come together to fight corruption in India.

5. http://www.ipaidabribe.com is one such site.

6. Another site which has recently sprung up is www.ekakizunj.com. It is inspired by Khairnar, the erstwhile Mumbai Municipal commissioner and intends to create a database of all the corrupt in India.

\section{SOCIAL VIOLENCE}

India is a land of multi-religions and multi-regions. While the earlier rulers and Indians took pride in the fact that India moved forward in spite of all the cultural and religious difference, it is a pity that in contemporary world, the same issue has become a reason for social violence existing in our country and a hurdle for development of the country. Social Violence most of the times backed by the politicians in-order to increase their vote bank or bank accounts. Be it the infamous Godhra Violence in Gujarat in 2002 or the Bombay Riots in 1992-1993 which were based on inter-religion clashes or the more recent Telangana issue in 2010 or the Maharashtra Navnirman Seva (MNS) backed communal issue in Mumbai which were based on inter-region clashes are recent examples of how India has been witness to social violence. Social Violence destroys lives and the livelihoods of citizens of the country, instills a sense of fear and insecurity in the common generation and 
has a profound negative impact on the development of our country. Apart from the religious and regional issues that result in the social violence, one of the major issues that result in social violence is the dissatisfaction of the system. Dissatisfaction from the system comes with broken promises, untimely services or denial of services or unheard or requests falling on deaf ears. An outbreak against the government is not only harmful because it may lead to large scale clashes between pro-government and anti-government but also make the government unstable or put it in jeopardy.

Social violence also occurs due to the victimization of the poor. The conditions of the poor in our country are pitiable with over 27\% living BPL (Below Poverty Line). With the advent of market economy, issues like poverty and unemployment have further deepened. In such a scenario, the poor can easily be misled not just against any government and are victimized in conflicts between the two political parties or any such organization. The same manpower that could have been used in the development of the country is now used against it, to hamper the growth and to put the democratic machinery in jeopardy. Social violence not only renders the government instable but also hampers the growth of youth and curbs the development of business and other services like hospitals and institutions. Social Violence also is responsible for shutting down schools and putting the economy of the country in standstill.

In the times of globalization, no country can be secluded from the rest of the world. What happens in India has direct consequences on its trade relations with other countries. A country that is so affected by not only factors like terrorism but internal violence like regional and religious violence would manage to attract investments from international funds and even if it does, it won't be optimal.

The following International Human reports list out the sorry state of Indian affairs at International level:

1. The 2008 Human Rights Watch report notes: India claims an abiding commitment to human rights, but its record is marred by continuing violations by security forces in counterinsurgency operations and by government failure to rigorously implement laws and policies to protect marginalized communities. A vibrant media and civil society continue to press for improvements, but without tangible signs of success in 2007.

2. The 2007 Amnesty International report listed several issues concern in India and noted Justice and rehabilitation continued to evade most victims of the 2002 Gujarat communal violence.

\section{CONCLUSION}

While the solutions to each of the problems that contribute as a barrier to development be it terrorism, corruption or social violence are more or less similar, it is important social violence is regarded as a separate issue. It is important to sensitize people not just about the religion but also the regions. An India that works for the betterment as a whole is required rather than working for upliftment of one particular community. Apart from that social violence is generally responsible for a sense of alienation, which creeps into the youth of different parts. It is important that problems of such areas are addressed and enough economic and social development takes place in those particular areas. Again stringent measures should be taken against the firebrands working in the society and against the politicians discriminating against religions or regions to increase their vote banks.

To have peace and harmony in a society like India, freedom of religion notwithstanding, it is important to discourage all kinds of discriminatory, divisive and regressive practices and influences such as casteism (one caste or vocation considered superior than the other), gender discrimination (one gender considered and treated better than the other), and religion-exclusionism (one religion considered and promoted as the best or only way to God or salvation).

\section{References}

Terrorism and Development Co-operation, Piet Terhal, International Workshop

Terrorism and Development, Kim Cragin and Peter Chalk, RAND, 2003

Combating Corruption for Development, Rule of Transparency, law and accountability, $10^{\text {th }}$ October 2002

United Nations Development Programme, Human Development Report 2002: Deepening democracy in a fragmented world (New York: Oxford University Press, 2002)

Economy of India, Wikipedia

Changes in Economic Life in India ( 1858-1947), Maheedhar Kaki, 13 Nov 2009

Corruption and Development, International Symposium on the Prevention and Control of financial fraud, 19-22 October 1988

Violence in India, IndianChild, 2000

Social Violence and the Social Institutions, Toma Tomov

The Geneva Declaration on Armed Violence and Development, Geneva, 7 June 2006 